\title{
Representing the 'Zionist Regime': Mass communication of anti-Zionism in the English-language Iranian Press
}

\author{
Rusi Jaspal, Ph.D. \\ De Montfort University, Leicester, UK
}

Anti-Zionism constitutes an important ideological building-block of the Islamic Republic of Iran (IRI). This paper provides insight into the mass communication of anti-Zionism in the English-language Iranian Press in order to examine how this ideology is 'exported' to an international readership. The paper presents the results of an empirical study of two leading English-language Iranian newspapers: The Tehran Times and Press TV. The study uses critical discourse analysis and draws upon tenets of Social Representations Theory from social psychology. The following discourses are discussed: (i) Resisting social representations of Israeli statehood; (ii) Constructing threat: The Zionist regime as a terrorist entity; and (iii) Responding to threat: Anti-Zionism as a religious duty for the Muslim Ummah. As a 'mouth-piece' of the IRI, these outlets adopt and encourage a fervently antiZionist stance by refusing to recognise the statehood and civilian population of Israel and by constructing the 'Zionist regime' as a terrorist threat which should be mitigated collectively by the Islamic Ummah. Implications are discussed.

Keywords: media representations; Iran; Israel; anti-Zionism; prejudice; social representations theory; critical discourse analysis; qualitative; social psychology

\section{CORRESPONDENCE}

Dr Rusi Jaspal, Self and Identity Research Group, Faculty of Health and Life Sciences, De Montfort University, Leicester LE1-9BH, United Kingdom. E-mail: rusi.jaspal@cantab.net

\section{ACKNOWLEDGEMENTS}

The author would like to thank the Iran Media Program, Annenberg Public Policy Center for their financial support of this research project.

\section{AUTHOR BIOGRAPHY}

Dr Rusi Jaspal is a Chartered Psychology and Lecturer in Psychology at De Montfort University, Leicester, UK, where he leads the Self and Identity Research Group. He holds degrees from the University of Cambridge, University of Surrey and Royal Holloway, University of London. Dr Jaspal has a long-standing interest in the inter-relations between social representation, identity and social action, especially in the context of prejudice. Rusi Jaspal is author of Antisemitism and Anti-Zionism: Representation, Cognition and Everyday Talk (Ashgate, 2014), and co-editor with Dame Glynis Breakwell of Identity Process Theory: Identity, Social Action and Social Change (Cambridge University Press, 2014). 


\title{
Representing the 'Zionist Regime': Mass communication of anti-Zionism in the English-language Iranian Press
}

\author{
Rusi Jaspal, Ph.D. \\ De Montfort University, Leicester, UK
}

Anti-Zionism constitutes an important ideological building-block of the Islamic Republic of Iran (IRI). Following the Islamic Revolution in 1979, anti-Zionism became an official policy in Iran and diplomatic relations with the State of Israel were suspended (Mahdi, 2003). The IRI vocally supports Palestinian sovereignty over the whole of present-day Israel, the West Bank and Gaza, while periodically calling for the destruction of the Jewish State. This position has drawn support from other Arab and Muslim countries, and condemnation from much of the Western world (Takeyh, 2006). There has been social sciences research into the development and deployment of anti-Zionism and anti-Semitism in the IRI (Jaspal, in press; Litvak, 2006; Shahvar, 2009), much of which has examined the political functions of this ideological stance (Küntzel, 2010; Takeyh, 2006). This paper makes a novel sociopsychological contribution to the literature by examining textual social representations of Israel in the Iranian Press. More specifically, the paper investigates how the IRI's anti-Zionist policy is 'exported' beyond the national and linguistics borders of Iran through a critical discourse analysis of a small sample of articles published in the English-language Iranian Press.

\section{Institutionalised social representations of Israel}

Zionism can be described as an 'ethnonationalist ideology', whereby Israel is regarded as 'the expression of the Jewish people’s right to national self-determination (Beller, 2007, p. 226). Conversely, the IRI regards Zionism as a racist and oppressive ideology, which it likens to Nazism (Takeyh, 2006). Since the IRI withdrew its recognition of the State of Israel following the Islamic Revolution in 1979, it has systematically referred to Israel as the 'Zionist regime' and 'Occupied Palestine'. It regards Israel as an occupation of Palestine, which is frequently depicted as 'Muslim land’ (Shahvar, 2009). The IRI is a major funder of the Hezbollah Movement in the Lebanon and of the Islamist party Hamas in the Palestinian Territories, both of which are regarded as terrorist organisations by the US and the EU and are committed to the destruction of the State of Israel (Palmer-Harik, 2004).

Social scientists have examined the nature of social representations disseminated by the IRI, particularly in political and media discourses (Jaspal, in press). Indeed, given the censorship of the media in Iran, political and media discourses tend to be mutually complementary, which is likely to produce coercive and uniform social representations. In his account of the motives underlying anti-Zionism and anti-Semitism in Iran, Jaspal (in press) has argued that the IRI deliberately disseminates anti-Zionist and anti-Semitic social representations in order (i) to maintain temporal continuity between the original tenets of the Islamic Revolution and the present-day Islamic Republic; (ii) to establish a sense of acceptance and inclusion in the largely Sunni Muslim Middle East; (iii) to exhibit the competence, influence and control of the IRI vis-à-vis Jews and Israel; (iv) to construct Israel as a threat which needs to be defeated by the Muslim world. However, it is important to examine how these motives are served by Iranian English-language media representations.

\section{Media representations of Israel}

Much existing research into the media in Iran tends to focus on media practices, journalistic tendencies, press censorship and the long-standing anti-Western position of the Iranian media since the Islamic Revolution (Semati, 2008; Sweetser \& Brown, 2010). Yet, there have been 
only cursory observations concerning how Jews and Israel are represented in the Iranian media in order to exemplify general points concerning institutionalised anti-Semitism and anti-Zionism in Iran (Litvak, 2006; Shahvar, 2009; Takeyh, 2006). This work has been useful in elucidating the relationship between political and media discourses in Iran and how the IRI disseminates its anti-Zionist ideology to the Iranian readership. However, there have been few systematic media analyses focusing specifically on how the English-language Iranian Press represents Israel. This is key to understanding how the IRI 'exports' its anti-Zionist ideology to an international readership in order to broaden its sphere of ideological influence beyond the national boundaries of Iran.

Klein's (2007) analysis of how the Iranian and Israeli media represented the Iranian nuclear issue and the Israeli-Palestinian conflict during a two-month period in 2007 is a notable exception. Using a small purposive sample of online articles, Klein examined the 'news frames' employed in Iranian and Israeli media reporting, respectively. It was found that the Iranian Press typically framed Israel as a 'savage regime' and enemies of Islam. However, Klein's period of analysis was dominated by a speech delivered by Iran's Supreme Leader concerning the International Qods Day, the annual Islamic 'resistance day' celebrated on the last day of Ramadan, which could explain these results. Conversely, the present study focuses upon more habitual representational practices in order to elucidate how Israel is represented to an international readership in the absence of politically 'polarising' events. Furthermore, it is concerned explicitly with the creation of meaning in the media, that is, how social representations of Israel are actually created, disseminated and encouraged in media reporting. Crucially, it offers a socio-psychological approach to textual social representations of Israel, bridging representation, identity and action. Social representations theory provides an ideal heuristic lens for this purpose.

\section{Social Representations Theory}

Social representations theory (Moscovici, 1988) was designed to address human responses, both cognitive and rhetorical, to scientific information, by treating seriously the information that circulates in society and the ideas in people's minds (Billig, 1988). A social representation is defined as a system of values, ideas and practices regarding a given social object, as well as the elaboration of a social phenomenon by a group for the purpose of communicating and behaving. Social representations of Israel in the media provide the readership with a shared social 'reality' and 'common consciousness' vis-à-vis Israel, facilitating meaning-making and 'appropriate' social and psychological responses to it (Klein, 2009).

In his analysis of how representations are formed, Moscovici (1988) outlines the processes of anchoring and objectification. Anchoring reflects the categorisation of unfamiliar objects through their comparison with an existing stock of familiar and culturally accessible objects. For the readership to develop an understanding of Israel, it must first be named and attributed familiar characteristics, which facilitate communication and discussion about it. For instance, Shahvar (2009) has observed that the Iranian Supreme Leader Ayatollah Khomeini frequently linked the Israeli-Palestinian conflict to the Jews' historical 'exploitation' of Muslims, thereby constructing Israel as the 'villain' in the Israeli-Palestinian conflict. Objectification is the process whereby unfamiliar and abstract objects are transformed into concrete and 'objective' common-sense realities. Jaspal (in press) has argued that, for the IRI, Israel is a tangible symbol of Jewish self-efficacy, that is, their autonomy, competence and control. A critical discourse analytical approach to anchoring and objectification can elucidate how these processes function discursively in the domain of text and talk (van Dijk, 1993). 
Social representations are shared and accepted by individuals to differing degrees (Moscovici, 1988). Hegemonic social representations are shared consensually by members of a group; they are coercive and relatively uniform. The illegitimacy of the State of Israel can be considered a hegemonic social representation in the Middle East (Kressel, 2007). Conversely, polemic representations are generated in the course of social conflict and are characterised by antagonistic relations between groups. Typically, polemic representations challenge existing hegemonic representations. The theory that the Zionists deliberately accentuate the number of Jews killed during the Holocaust could be described as a polemic representation (Litvak, 2006). Moving beyond social representations, certain ideas regarding Israel and Jews may in fact constitute nexuses, which refer to indisputable ideas and symbolic emblems that correspond to 'prelogical affective knots shared by a large number of individuals' (Rouquette, 1994, p. 60). Nexuses differ from social representations in that they constitute 'a more narrow, more radical, more collective and more mobilising modality' with important implications for social behaviour (Ernst-Vintila, Delouvée \& Roland-Lévy, 2011, p. 297). Moreover, Cinnirella (1997) has argued that social representations can become dormant over time, although the interaction of social and psychological factors can reactivate them. Clearly, social power plays an important role in determining whether social representations are to remain active or become dormant and whether they are hegemonic, polemic or more akin to a nexus; power relations determine the influence a group has in disseminating and 'hegemonising' its representations (Breakwell, 2001). This paper investigates how polemic representations can be 'hegemonised' in media discourse.

\section{Aims}

This study examines (i) how the processes of anchoring and objectification are employed in media discourse in order to generate particular social representations of Israel; (ii)how polemic representations of Israel are consolidated; (iii)the implications of these representations for intergroup relations.

\section{METHOD}

\section{Critical discourse analysis}

This study presents a fine-grained critical discourse analysis (CDA) of a small corpus of articles concerning Israel (van Dijk, 1993). CDA is a language-oriented analytical technique for identifying patterns of meaning within a data set. It aims to integrate discourse, cognition and power, and to bridge the epistemological positions of social constructionism and realism. The technique provides insight into how social reality is constructed in talk and text, acknowledging the possibilities offered by, and potential constraints imposed by, social power relations (van Dijk, 1993). CDA helps reveal the rhetorical strategies for affirming and contesting hegemonic and polemic social representations of Israel and indeed how polemic representations can be elevated to hegemonic position (Jaspal \& Yampolsky, 2011).

CDA was considered particularly useful due to its theoretical foci, which lie in describing (i) control, that is, how groups exert control over others through persuasion or by constructing their agenda as 'natural'; (ii) social cognition, namely that discourse can create and feed into social representations; and (ii) rhetorical strategies, namely the ways in which stakeholders rationalise and contest particular representations of Israel. These theoretical concerns within CDA are crucial for understanding how institutionalised representations (associated with the IRI) can become popularised at the social level (Jaspal, in press).

\section{Data collection and procedure}

This study focuses upon two English-language Iranian news outlets, namely The Tehran Times and Press TV. 
The Tehran Times is a daily newspaper published in both print and online formats. It was established by Ayatollah Seyyed Mohammad Beheshti following the Islamic Revolution in 1979. According to Behesti, "[t]he Tehran Times is not the newspaper of the government; it must be a loud voice of the Islamic Revolution and the loudspeaker of the oppressed people of the world" ${ }^{1}$. Although the newspaper is not state-owned, it aims to disseminate key tenets of the Islamic Revolution and is therefore generally supportive of IRI's ideology. According to its website, The Tehran Times 'makes a special effort to publish reports on cultural and religious issues', in addition to various other social issues. Although there are no independent data concerning the circulation of the outlet, The Tehran Times claims to be 'attracting readers from over 80 different countries' and that its website has 'over 10,000 visitors each day'.

Press TV is a state-owned media outlet, which forms part of the Islamic Republic of Iran Broadcasting Corporation. It was launched in 2007 to 'counter' Western news reporting on global issues (in particular, the Middle East). The outlet targets the West as its primary readership. The official vision statement of Press $T V$ is to 'to heed the voices and perspectives of the people of the world; build bridges of cultural understanding; encourage human beings of different nationalities, races and creeds to identify with one another; bring to light untold and overlooked stories of individuals who have experienced political and cultural divides firsthand.' Like The Tehran Times, Press $T V$ is similarly conservative in its ideological stance, and has been described as a 'mouth-piece' for the IRI.

Both The Tehran Times and Press TV websites feature an online database of published articles, all of which are available in PDF format. Using the keywords 'Israel', 'Zionist' and 'Palestine', the author conducted a search of the online databases for articles published between $1^{\text {st }}$ May 2011 and $1^{\text {st }}$ September 2010. 214 articles published during this 4month period contained one or more of these keywords and were included in the output. All of these articles were subjected to critical discourse analysis. The aim of the study was to provide a fine-grained CDA of the discursive aspects of media reporting on Israel, rather than to provide a longitudinal overview of media reporting. The aim was theoretical, focusing on how representations are constructed, disseminated and encouraged, rather than purely empirical. It was decided that a relatively small and well-circumscribed corpus of articles published during a short space of time would be adequate for fulfilling this research aim. Moreover, a key aim of the study was to examine habitual ways of media reporting on Israel, rather than polarised coverage of particularly contentious events (e.g. Lebanon War; Gaza War). Thus, it was deemed appropriate to target a time-period in which there were no reports of major social or political events concerning Israel/the Israeli-Arab conflict. Although there are frequent skirmishes between the Israeli army and Palestinian militants as well as rocket attacks from Gaza, which often feature in international news coverage (Philo \& Berry, 2004), the aforementioned 4-month period was in fact relatively uneventful.

All articles were read repeatedly. The right margin was used to note emerging theme titles which captured the qualities of the articles. This procedure was repeated with every article. These initial codes included inter alia the general tone of the article, categorisation (e.g. 'regime'), positioning (e.g. victimhood versus perpetrator), particular forms of language (e.g. metaphor), and emerging patterns within the data. Subsequently, the right margin was used to collate these initial codes into potential discursive themes, which captured the essential qualities of the articles analysed. Codes were pieced together in order to create discursive themes. The themes were reviewed rigorously against the corpus in order to ascertain their compatibility and numerous extracts from the articles were listed against each corresponding theme. Specific article extracts, which were considered vivid, compelling and representative of the discursive themes, were selected for presentation. Finally, three superordinate discursive themes representing the results were developed and ordered into a 
logical and coherent narrative structure. Relevant constructs from SRT were drawn upon as a means of theoretically enriching the analysis.

\section{ANALYSIS}

The analysis discusses the following themes: (i) Resisting social representations of Israeli statehood; (ii) Constructing threat: The Zionist regime as a terrorist entity; and (iii) Responding to threat: Anti-Zionism as a religious duty for the Muslim Ummah.

\section{Resisting social representations of Israeli statehood}

The IRI regularly contests the legitimacy of the State of Israel, evidenced by the disparaging ways in which it refers to the Jewish State in political discourse (Shahvar, 2009). Similarly, there was a clear tendency in the corpus to resist social representations of Israeli statehood, by conversely constructing Israel in terms of a 'regime':

1. The IAEO [International Atomatic Energy Organisation] chief said that the Zionist regime's agents carried out the terror plot with the help of the US and UK spying agencies ${ }^{2}$

2. The Tel Aviv regime has ordered the Israeli navy to use all possible means to prevent the incoming international aid flotilla from reaching the Gaza Strip ${ }^{3}$

3. Yet Tel Aviv...continues to accuse the European governments of negligence in backing the Hebrew regime ${ }^{4}$

The category 'regime' has negative connotations of an authoritarian form of government and, thus, its use here serves to further negativise Israel. Use of this category is consistent across the whole corpus of articles, although it is characterised differentially in terms of the 'Zionist, 'Tel Aviv', 'Hebrew' or 'Israeli' regime. The use of 'Zionist regime' in extract 1 seems to further anchor this 'authoritarian regime' to a political ideology which itself has acquired negative connotations (Takeyh, 2006). Indeed, the political ideology of Zionism is frequently represented in negative terms as an 'expansionist' colonial ideology, rather than as the politico-national aspiration of the Jewish people (Litvak, 2006).

Extract 2 refers to the 'Tel Aviv regime' and thereby constructs the city of Tel Aviv as the centre of the 'authoritarian' regime, despite the fact that Jerusalem is the political capital of Israel and the location of the Israeli Knesset (Parliament). This serves to distance the 'regime' from the city of Jerusalem, which the IRI regards as Islamic territory and refers to by its Arabic name 'Al-Qods' (Tayekh, 2006; see extract 20). Similarly, the designation of Israel as 'the the Hebrew regime', as in extract 3, delegitimises the Jewish administration of Israel, by characterising it as a 'regime'. Indeed, the IRI has repeatedly manifested its view that Palestine is in fact 'Muslim land' and that the Jewish population of Israel is illegitimate (Shahvar, 2009).

The articles further resist social representations of statehood by referring to Israelis as 'Zionists', rather than as citizens of the State of Israel.

4. The Zionists are worried about the grass-roots uprisings in the Middle East ${ }^{5}$

In both political and media discourses, the category 'Zionist' is commonly employed to substitute the demonym 'Israeli', which serves to anchor the seldom-mentioned people of Israel to the political ideology of Zionism. (It is noteworthy that the articles seldom made reference to the people of Israel.) Thus, the citizens of Israel are depicted 
primarily as adherents of the stigmatised political ideology of Zionism. This contributes to the 'politicisation' of the people of Israel, since their identities as both individuals and citizens of the State of Israel are completely attenuated vis-à-vis their constructed affiliation and adherence to the political ideology of Zionism. The 'politicisation' of the Israeli people foregrounds the 'regime', rather than the citizenry, that is, the Israeli people. In short, Israel is not represented as a legitimate state at all but rather as a 'regime', whose members are 'Zionists', not Israelis. This serves to rhetorically 'depopulate' the State of Israel, objectifying the 'Zionist entity' as a malevolent 'regime' rather than a people consisting of human beings (Klein, 2009).

Although the 'regime' is most frequently characterised as a 'Zionist' one, some articles in the corpus did in fact make reference to 'Israel' and its demonym 'Israeli':

5. Although Tel Aviv had previously prepared itself for hostilities, the Israeli regime was forced into starting the conflict ${ }^{6}$

Clearly, use of the demonym 'Israeli' does not at all serve to legitimise the State of Israel, although this may appear to constitute a departure from the IRI's insistence on referring to the Jewish State as a 'regime' and 'Occupied Palestine' (Küntzel, 2010). Rather, it continues to construct Israel primarily in terms of a 'regime' and only acknowledges Israel insofar as this is the name given by the 'occupiers' to their regime. Crucially, when the category Israel is mentioned, it is habitually accompanied by imagery of occupation and even genocide (see extract 11), establishing social representational linkage between the category 'Israeli' and negative imagery of occupation and genocide (against the Palestinians).

Indeed, many articles in the corpus refer to an Israeli occupation of Palestinian land, although it is sometimes unclear whether 'occupied territory' refers to the West Bank (which indeed is recognised by the UN as an occupation) or to the State of Israel (which the IRI regards as 'Occupied Palestine'). However, the following extract clearly represents the entire State of Israel as ‘Occupied Palestine’.

6. The recent massive demonstrations in occupied Palestine are regarded as public protest against the economic situation and unemployment ${ }^{7}$

Referring to the widespread protests against the rising costs of living in Israel, the extract expresses Israeli public protest against a domestic issue as 'demonstrations in occupied Palestine'. The newspapers consistently resist social representations of statehood and thereby downplay the existence of the people of Israel vis-à-vis the 'Zionist regime'. When citizens of Israel are mentioned, they tend to be politicised in terms of 'Zionists' (see extract 4). Yet, this particular article does refer to the popular protests of the Israeli people, which gives rise to a tension between the dominant tendency to resist social representations of Israel as a state with its own citizenry, on the one hand, and acknowledging the reality that Israeli citizens exist, live in Israel and participated in public protests against their government. However, it seems that this story is covered in accordance with the dominant ideology of the IRI, which officially regards the whole State of Israel as 'Occupied Palestine', by anchoring the Israeli protestors to occupation and colonialism. Although the extract acknowledges that this constitutes a case of 'public protest', the public itself is positioned within 'occupied Palestine', rather than in their 'own' state. This represents the people of Israeli as occupiers, rather than legitimate citizens. One interpretation of this discourse is that the power of the regime is decreasing given its alleged 'internal problems' ${ }^{8}$ 
In addition to the particular categories employed in order to refer to the State of Israel, articles objectified the 'regime' in terms of a tangible, malevolent and threatening entity.

7. The regime is a cancerous tumor that will metastasize if even a small part of it remains on Palestinian soil ${ }^{9}$

It has been shown that the political rhetoric in the IRI tends to construct the State of Israel in terms of a threat to the IRI, to Muslims and even to the West (Jaspal, in press). Extract 3 draws upon imagery of threat by objectifying the State of Israel in terms of a 'cancerous tumor'. Objectification in this way serves to construct what is already represented as an authoritarian 'regime' as a growing threat in need of immediate attention. The metaphor of a 'cancerous tumor' is effective in creating a sense of mortal threat, on the one hand, since cancerous tumours actively undermine human life, as well as a sense of urgency, given the proclivity of malignant tumours to metastasize, posing a more dire threat to the victim. Incidentally, the extract explicitly employs the verb 'metastasize', which forms part of the semantic field of cancer.

Crucially, 'the regime' is constructed in terms of an inanimate, dehumanised entity which actively poses a mortal threat to its host, namely the Palestinians. Here too stereotypical power differentials between the Israelis and Palestinians are reproduced in order to construct Israel as an authoritarian, malevolent regime, on the one hand, and the Palestinians as the eternal victims of this mortal threat, on the other. Anchoring Israel to malevolence and threat, and the Palestinians to the category of victimhood, reproduces these stereotypical power relations. Furthermore, the objectification of Israel in terms of an inanimate, yet authoritarian entity represents it as threatening and utterly devoid of humanity. The processes of anchoring and objectification collectively serve to encourage some form of action against the 'regime'. Similarly, Jaspal (in press) has argued that political rhetoric in the IRI frequently represents Israel as a 'hybridised', multi-faceted threat, with the aim of mobilising the Islamic Ummah against the State of Israel.

\section{Constructing threat: The Zionist Regime as a terrorist entity}

Articles in the corpus represent Israel as a threat by anchoring it to terrorism. Anchoring performs an attributional function by constructing the 'Zionist regime' as responsible for domestic 'terrorist attacks' in the absence of any legal evidence (Moscovici \& Hewstone, 1983).

8. MP Kazem Jalali of the Majlis National Security and Foreign Policy Committee has also said that the assassination was an indiscriminate terrorist operation, adding that the Iranian nation knows that the Zionist regime...is behind these terrorist attacks...The Zionist regime and the U.S. are the axis of terrorism in the world ${ }^{10}$

The assassination of the Iranian nuclear scientist is described in terms of an 'indiscriminate terrorist operation', which represents Israel as a threat with the intention to harm indiscriminately the Iranian nation, rather than to assassinate one particular individual. This performs a 'collectivising' function in that the assassination of one individual is constructed as threatening to the entire nation (Jaspal \& Nerlich, in press). Moreover, this event is invoked in order to argue that the 'Zionist regime (and the US)' are 'the axis of terrorism in the world'. In short, Israel is represented as leading global terrorism.

In the absence of any objective evidence to link Israel to the assassination, the article attributes this accusation to the political figure MP Kazem Jalali, whose membership in a 
security and foreign policy governmental organisation is emphasised. This lends the speaker a degree of credibility in the eyes of the reader, which in turn lends credibility to his statement of Israel's culpability. This rhetorical technique of disseminating a social representation through the quotation of a 'socially powerful' source has been referred to as strategic quoting (Jaspal, 2011). Indeed, 'powerful' individuals such as politicians and 'experts' usually have greater clout in disseminating social representations (Breakwell, 2001). This polemic representation is further reiterated not only through the strategic quoting of an 'expert' by also by constructing this knowledge as commonsensical. The 'Iranian nation', that is, the people of Iran, are said to be aware of the culpability of the 'the Zionist regime'. Thus, this polemic representation is hegemonised through its attribution to the general population, rather than to the Iranian government.

Furthermore, even before the trial of the suspect arrested in connection with the assassination, articles in the corpus construct the implication of Israel in the 'terrorist attacks' as imminent and certain. This 'knowledge' is constructed as commonsensical:

9. The trial [of Ali Jamali-Fashi who was accused of assassinating a nuclear physicist] will shed light on the Zionist regime's involvement in terrorist attacks against the Iranian people ${ }^{11}$

Use of the future tense 'will', rather than the more tentative auxiliary verb 'may', further hegemonises the representation. The extract clearly represents the 'Zionist regime' as a terrorist entity by constructing its alleged involvement in the assassination as an act of terror against the Iranian people, rather than against the Iranian nuclear programme, the government or a particular individual. Thus, the threat is collectivised to the entire nation (Jaspal \& Nerlich, in press). This polemic representation is juxtaposed with and supported by the more established representation (in the Arab world) of Israeli 'terrorist action' against the Palestinian people:

10. The Zionist regime's terrorist action against the defenseless and innocent Palestinians was an attempt to shift focus away from its internal problems just ahead of the International Qods Day ${ }^{12}$

Extract 10 makes clear reference to the hegemonic representation that the stateless Palestinians are 'defenseless and innocent' (the constructed victims of the 'Zionist regime') in order to represent Israel as a terrorist entity. Not only does the 'Zionist regime' engage in terrorist action but it does so against a 'defenseless' people. The 'de-populated' and dehumanised 'Zionist regime' is positioned as the aggressor, while the Palestinians are positioned as their victims. In short, the observations that Israel launches attacks against the 'Iranian nation' and the 'defenseless and innocent Palestinians' contribute to the overarching representation that Israel is a brutal terrorist entity. As exemplified by extract 10, articles elaborated this representation by alluding to the reasons allegedly underlying this 'terrorist action'; this is frequently attributed to Israel's desire to 'shift focus away from its internal problems'. Thus, while the articles represent Israel as a threat and terrorist entity, it is simultaneously implied that Israel is inherently weak and on the verge of destruction due to its 'illegitimacy' (Jaspal, in press).

As mentioned, there is an existing hegemonic representation of the plight of the Palestinians, which is observable in the global media (Litvak, 2006). Articles in the corpus juxtapose this hegemonic representation of Palestinian suffering with the polemic representation that Israel actively and malevolently commits atrocities and terrorist acts. This too contributes to the representation of Israel as a terrorist entity: 
11. The bodies of "more than 350" Palestinians killed by Israel in the past 64 years still remain in Israel's Cemetery of Numbers, which is described as "mass graves for Palestinians"13

12. Another [Turkish] demonstrator said, "We see Maccabi Tel Aviv [football team] a representative of Israel that is responsible of massacres in Gaza and at the Mavi Mamara"14

In extract 11, there is a clear focus upon the Palestinian people, rather than Palestinian militants or combatants. This ambiguity in categorisation constructs the Israeli-Palestinian conflict as one between the State of Israel and the people of Palestine. Moreover, the characterisation of the Palestinian cemetery as 'mass graves for Palestinians' serves to depict Israel as guilty of genocide against the Palestinian people. The term 'mass graves' evokes imagery of genocide. Similarly, in extract 12, a Turkish protestor is strategically quoted as constructing Israeli military action both during the Gaza War and in the Turkish Flotilla incident in terms of 'massacres'. The metaphor of 'massacre' indeed forms part of the semantic field of genocide. The strategic quoting of a Turkish protestor serves to hegemonise this polemic representation, since this is constructed as 'common knowledge' shared not only by Iranians and Palestinians but also by Turks. The fact that Turkey is usually considered to be an ally of Israel, makes the quoting of a Turkish critic of Israel particularly 'strategic' (Jaspal, 2011).

In one article, the political ideology of Zionism, which dominates imagery of Israel in Iranian political and media representations, is more explicitly anchored to terrorism, further constructing the 'Zionist regime' as a terrorist entity:

13. Norway mass killer is pro-Zionist...Anders Behring Breivik, who killed at least 93 people in a bomb attack and shooting rampage in Norway, has claimed he is pro-Zionist ${ }^{15}$

These outlets very scantily covered the terrorist attacks perpetrated in Norway. In extract 13, these attacks are implicitly attributed to the (irrelevant) political ideology of Zionism. Indeed, van Dijk (1993) discusses the rhetorical strategy of 'overcompleteness/ irrelevance', whereby newspaper discourse provides subordinate, yet superfluous information of little relevance to the report itself, in order to confirm and contribute to negative social representations of the stigmatised 'Other'. Breivik has most commonly been associated with extreme right-wing extremism and ultra-nationalism (Blair, 2012). However, these ideologies are not mentioned in the article. Rather, Zionism is given centre stage, which implies that his adherence to this political ideology may somehow explain his 'bomb attack and shooting rampage'. The categories 'terrorist'/ 'mass killer' and 'pro-Zionist' are rhetorically entwined, establishing social representational linkage between them. This contributes to the social representation that Israel is a terrorist entity by 'normalising' the links between these practice of mass killing and the ideology of Zionism. This polemic representation must be examined within the context of existing social representations that Israel has perpetrated deadly attacks against the Palestinians, resulting in 'massacres' (see extract 12; Litvak, 2006). In short, Breivik's 'pro-Zionist' stance is implicitly constructed as the underlying cause of his terrorist actions. 


\section{Responding to threat: Anti-Zionism as a religious duty for the Muslim Ummah}

Articles in the corpus construct Israel as a 'hybridised' threat to Islam, that is, one which threatens the Islamic 'worldview' as well as the survival of Muslims (Jaspal \& Cinnirella, 2010):

14. Israelis burn mosque, Qur'ans...Numerous copies of the holy Qur'an were also burnt $^{16}$

15. The Israeli regime has demolished a mosque near Tubas in the West Bank...This is the third mosque demolished by forces of the Israeli regime ${ }^{17}$

16. Sadr [Second Deputy Speaker of the Iranian Parliament] added that the Zionist regime is spending massively to instigate turmoil and insecurity in Muslim Syria ${ }^{18}$

Extract 14 attributes arson attacks against a mosque to 'Israelis' in general, rather than to any particular subgroup, such as Jewish settlers in the West Bank, for instance. This is analogous to the observation that Western newspapers frequently attribute global terrorism to Muslims in general (Jaspal \& Cinnirella, 2010), which can anchor Islam to terrorism (Cinnirella, 2012). In this case, the national category 'Israeli' is anchored to attacks against Muslims. Having attributed these attacks to Israelis in general, the article proceeds to explain that the Islamic Qur'an was also burnt. Similarly, extract 15 further constructs 'the Israeli regime' as a threat to Islam by highlighting a series of Israeli-led demolitions. Use of the verb 'raze' in the title of the article constructs this as a complete destruction, further accentuating the threat allegedly posed by the 'Israeli regime'. The acts of burning and destroying Islamic places of worship and the Islamic Holy Book construct the seldom-mentioned Israeli people, as well as the 'Israeli regime', as posing a hybridised threat to Islam. Extract 16 depicts the 'Zionist regime' as resourceful in its attempt to 'instigate turmoil and insecurity' in Muslim land. This is consistent with the representation that the 'Zionist regime' is malevolent and committed to the destruction of Islam (Klein, 2009). Crucially, this is constructed as Zionist aggression against a Muslim country, which represents Israel as a threat to Muslims.

Articles explicitly link the social representation that Israel constitutes a hybridised threat to Islam with the emancipated representation that Muslims should collectively mobilise against Israel:

17. Jalili [Secretary of Iran's Supreme National Security Council] said the liberation of Palestine could serve as the unifying point of Islamic Awakening movements in different countries and could...restore the rights which have been downtrodden by the Zionist regime ${ }^{19}$

18. [Iran's Deputy Defence Minister Vahidi stated that]"It seems as if the second wave of Islamic Awakening in...the fight against the Zionist regime (of Israel) is starting to reveal itself...This awakening will remove all obstacles from its way, and this anti-Zionist wake will take form in other Muslim countries”20

Although extract 17 refers to the injustices allegedly perpetrated by Israel in the IsraeliPalestinian conflict, the implications of these injustices are generalised to the Islamic Ummah. The extract constructs the 'Zionist regime' as deliberately curtailing the rights of the Palestinians, which reiterates the threatening nature of Israel. Given that Iranian political rhetoric frequently accentuates its superordinate self-categorisation as Muslims, injustices against the Palestinians are constructed as similarly relevant to the Iranian nation (see also 
extract 19). Crucially, social action against the 'tyranny' of Israel and, more specifically, 'the liberation of Palestine' are represented as the 'unifying point of the Islamic Awakening', that is, an ideological bridge between the global Muslim Ummah (Jaspal, in press). Both extracts 17 and 18 describe what has been referred to as the 'Arab Spring' as the 'Islamic Awakening', that is, they seem to Islamicise the Arab Spring. In short, mobilisation against Israel and commitment to its destruction (implied by the 'liberation of Palestine) are constructed as a pan-Islamic 'duty'. Similarly, in extract 18, the struggle against the 'Zionist regime' is depicted as central to the aforementioned 'Islamic Awakening'. Anti-Zionism is Islamicised by anchoring it to the Arab Spring (or 'Islamic Awakening'). More specifically, the extract represents anti-Zionism as the global and imminent product of the Islamic Awakening and thereby constructs it as a religious duty for Muslims.

The Ministry of Culture and Islamic Guidance is strategically quoted in order to represent the issue of Palestine as a key Islamic concern:

19. Iran’s Ministry of Culture and Islamic Guidance has released a multimedia CD on Zionism in Tehran... "Palestine is the main issue of the Islamic world and we could not be indifferent to the 60 years of tyranny perpetrated by the Zionists,” Hosseini [the Iranian Culture Minister] mentioned. ${ }^{21}$

The fact that this particular governmental department has released a CD on Zionism is telling - it is constructed as a cultural and, more specifically, an Islamic concern. Moreover, the Culture Minister is strategically quoted as referring to Palestine as 'the main issue of the Islamic world' and as urging Muslims to exhibit concern for the Palestinian cause. The social representation that the 'Zionists' pose a tyrannical threat to the Palestinians and Muslims, more generally, is strategically invoked in order to construct the emancipated representation that anti-Zionism is a religious 'duty'. The strategic quote depicts anti-Zionism as a core selfaspect associated with Islam.

Several articles in the corpus rhetorically accentuate the anti-Zionist tenet of Islam by highlighting the engagement of 'Muslim nations' in the Israeli-Palestinian conflict:

20. Muslim nations are now more determined than ever in their efforts to liberate all of the occupied territories, including occupied holy Qods...International Qods Day is a day of solidarity with Palestine observed on the last Friday of the holy month of Ramadan. ${ }^{22}$

21. Ramadan is one of the means for solidarity among Muslims... we should remember that the Zionist Regime and the United States are the common enemies of all Muslims. ${ }^{23}$

Extract 20 constructs anti-Zionism as a Muslim duty. This process of 'liberating' Palestine is optimistically represented as being already under way. In extract 20, the need to 'liberate' Palestine is clearly anchored to Islamic duty through the 'overcompleteness/ irrelevance' rhetorical strategy; the 'day of solidarity' is constructed as an Islamic duty through its anchoring to the 'holy month of Ramadan'. Similarly, extract 21 explicitly represents antiZionism as a common self-aspect of Islam by designating the 'Zionist regime' as a 'common' enemy of Muslims. The dictum regarding Muslim solidarity implies that it is necessary for all Muslims to espouse anti-Zionism in order to maintain a unified Islamic stance. In short, these articles represent anti-Zionism as a necessary religious duty for the global Islamic Ummah. 


\section{DISCUSSION}

This paper makes a novel socio-psychological contribution to the debate concerning IRI-led anti-Zionism by providing a social representations analysis of two English-language Iranian Press outlets. Through the rhetorical techniques of (i) providing 'overcomplete' superfluous information, (ii) strategic quoting and (iii) anchoring emerging polemic representations to well-established hegemonic ones, these outlets construct, disseminate and encourage negative social representations of Israel. Consistent with the ideology of the IRI, they adopt an unequivocally anti-Zionist stance and present Israel in terms of a 'regime', a global terrorist threat, as well as the central concern of the Islamic Ummah.

\section{Social representations of Israel}

Social categorisation facilitates the construction of ingroup/outgroup social identities, maintains their delineation, and imbues the groups with valence (Tajfel, 1981). The two outlets resist social representations of Israeli statehood, which serves to delegitimise the existence of the State of Israel. Moreover, there is no acknowledgement of Israel's civilian population, which leads to a rhetorical 'de-population' of Israel. Instead, the category of 'regime' politicises the civilian population. In some articles, the government and the people are collectively referred to as 'Zionists', rather than in terms of their (Israeli) citizenship, which similarly serves to anchor them primarily to the political ideology of Zionism. Zionism itself is largely stigmatised in Arab, Muslim and even some Western contexts, given that it is frequently anchored to racism and Nazism (Takeyh, 2006). Incidentally, articles further negativise Zionism by anchoring it to the terrorist actions of the Norwegian mass murderer Anders Breivik, who was convicted of killing 77 individuals in shooting and bombing campaigns. These forms of categorisation essentially reinforce a social representation, which is hegemonic in Muslim Middle Eastern societies, that Israel is an illegitimate 'regime' in 'Occupied Palestine’ (Webman, 2010).

Articles actively draw upon threat imagery. The inanimate, non-human 'Zionist regime' is represented as espousing terrorism, thereby appearing to pose a 'hybridised' threat to the ingroup (Jaspal \& Cinnirella, 2010). Anchoring Israel to terrorism performs an attributional function, since this 'evil Other' is hastily represented as a scapegoat (Lewis, 2003). By anchoring 'Zionist terror' against the Iranian people to the 'Zionist genocide' of the Palestinian people, the articles create an atmosphere of suspicion of the 'Zionist Other', since individuals are encouraged to transfer knowledge of 'Palestinian suffering' to other groups. The 'Zionist threat' is thereby constructed as global (Webman, 2010). Crucially, the social representation that the 'Zionist regime' is a terrorist entity, which actively seeks to harm Iranians and Muslims, more generally, performs a collectivising function, therefore encouraging collective mobilisation against Israel.

Although the English-language Iranian Press is keen to differentiate between antiZionism and anti-Semitism, while actively espousing an anti-Zionist position, the IRI's stance in fact seems to be 'religiously defined, as a struggle between a pristine Islamic cilivization and a blasphemous Zionist creed' (Takeyh, 2006, p. 84). Similarly, articles in the corpus represent the conflict as a key Islamic concern by anchoring it to Islamic occasions for 'solidarity' such as Ramadan, the International Qods Day and more recently the 'Islamic Awakening' (that is, the Arab Spring). It comes to dominate these collective aspects of Islam, establishing itself as a key tenet of religious participation. Crucially, this is facilitated by constructing Israel as a hybridised threat to Islam - individuals typically worry about the well-being and continuity of their immediate ingroups (Cohen, 2001). Anti-Zionist is implicitly constructed as a 'duty' for the Muslim Ummah. Consequently, indifference to the Israeli-Arab conflict is made to appear 'un-Islamic'. 


\section{Psychological motives and social action}

The link between social representation and social cognition is of crucial importance (van Dijk, 1993). Bernard Lewis (2003, p. 93) has argued that 'Israel serves as a useful stand-in for complaints about the economic privation and political repression under which most Muslim peoples live' and that anti-Zionism may constitute a means of 'deflecting the resulting anger'. Moreover, it has been argued that media representational strategies may reflect broader socio-psychological motives (Jaspal \& Cinnirella, 2010). In explaining the anti-Zionist stance of the IRI, Jaspal (in press) has suggested that this stance may help to establish (i) a sense of belonging in the predominantly Sunni Muslim Middle East, (ii) feelings of self-efficacy vis-à-vis Israel (and the Jews) and (iii) a sense of continuity over time. Indeed, it is easy to see how the media's representation of Israel as a common concern for the Islamic Ummah and the accentuation of Iran's role in uniting the global Islamic Ummah's in this common concern could promote feelings of ingroup belonging and selfefficacy (competence and control), respectively.

Moreover, there may be a desire for establishing acceptance, inclusion and belonging in the broader global context, that is, the West, which is often critical of the IRI's demonisation of Israel and Jews (Takeyh, 2006). As a 'mouth-piece' of the IRI, these outlets seek to export its ideology beyond the borders of Iran in a socially acceptable manner.

Clearly, the frequent overtly anti-Semitic diatribes of the Iranian leadership (Shahvar, 2009) would likely be deemed inappropriate by much of the intended Western readership of these English-language outlets. The implicit aim of these outlets may be to further rationalise the anti-Zionist stance, upon which the IRI depends (Jaspal, in press), by anchoring the 'regime' to threat and terror and by objectifying it in terms of a harmful 'cancer'. Although it may be tempting to underestimate the clout of these outlets in encouraging fervent anti-Zionism beyond the borders of Iran, some groups in society may be particularly vulnerable to the delegitimising social representations disseminated by these outlets. For instance, media research with British Muslims has shown that this group may distrust the mainstream British Press due to the perception that it is 'biased' (Jaspal, 2011). This may lead disaffected Muslims to explore alternative news outlets such as The Tehran Times and Press TV, which promise to be "the loudspeaker of the oppressed people of the world". Social representations disseminated by these outlets may be uncritically accepted by sections of the British Muslim community. In an important study of anti-Semitism among young British Muslims, Jiheli (2009) found that participants generally associated enmity with Jews with their Muslim identity and that the Israeli-Palestinian conflict served as a key rationale for their antiSemitism. Consequently, the fervent anti-Zionism embodied in Iranian media representations could further fan the flames of anti-Semitism among disaffected Muslim youth.

In linking social representations and social action, it seems appropriate to recall that ' $[w]$ hen people believe firmly that they are on the side of good and are working to make the world a better place, they often feel justified in using strong measures against the seemingly evil forces that oppose them' (Baumeister, 1997, p. 377). Crucially, articles consistently construct Israel as a malevolent, oppressive, terrorist 'regime' which is antithetical to the values of Islam. They represent mobilisation against Israel as a necessary duty for 'good' Muslims. Moreover, the 'regime' is rhetorically dehumanised and 'de-populated', thereby obscuring the civilian population of Israel. Kelman (1976) states that dehumanisation serves to deprive individuals of agentic and collective aspects of humanness, which can result in their failure to evoke compassion among perpetrators of abuse and violence. Accordingly, dehumanised victims are seldom shown any mercy. Thus, dehumanising and demonising social representations may serve to construct Israelis (and perhaps Jews in general, Jiheli, 2009) as a legitimate target for discrimination, abuse and even violence. The implications for intergroup relations could be devastating. This in turn is likely to encourage defensive 
responses from both the Israeli government and society, which are characterised by a 'siege mentality' whereby the Jewish Israeli ingroup is perceived to be perpetually threatened by outgroups (Bar-Tal \& Antebi, 1992).

\section{Conclusion}

This paper describes how social representations are created, disseminated and encouraged in a small sample of English-language Iranian Press articles. As a 'mouth-piece' of the IRI, these articles adopt and encourage a fervently anti-Zionist stance by refusing to recognise the statehood and civilian population of Israel and by constructing the 'Zionist regime' as a terrorist threat which should be mitigated collectively by the Islamic Ummah. This inflammatory rhetoric is exported to a Western readership in order to globalise the antiZionist ideology of the IRI, which could lead to irrational delegitimisation of the State of Israel, increased anti-Semitism, negative intergroup relations and an accentuation of the Israeli 'siege mentality'. It is hoped that this paper will draw attention to the pressing sociopsychological concern of anti-Zionism.

\section{REFERENCES}

Bar-Tal, D. \& Antebi, D. (1992). Siege mentality in Israel. International Journal of Intercultural Relations, 16, 251-275.

Baumeister, R. (1997). Evil: Inside Human Violence and Cruelty. New York: Freeman.

Beller, S. (2007). In Zion's hall of mirrors: A comment on Neuer Antisemetismus? Patterns of Prejudice, 41, 215-238.

Billig, M. (1988). Social representation, objectification and anchoring: a rhetorical analysis. Social Behaviour, 3, 1-16.

Blair, D. (2012). 'I would have done it again': Anders Breivik claims his massacre was motivated by 'goodness not evil'. The Telegraph, 17 April 2012.

Breakwell, G.M. (2001). Social representational constraints upon identity processes. In K. Deaux \& G. Philogene (eds.), Representations of the Social: Bridging Theoretical Traditions (pp.271-284). Oxford: Blackwell.

Cinnirella (1997). Ethnic and national stereotypes: a social identity perspective. In C.C. Barfoot (Ed.), Beyond Pug's tour: national and ethnic stereotyping in theory and literary practice (pp. 253-274). Amsterdam: Editions Rodopi.

Cinnirella, M. (2012). Think 'Terrorist', think 'Muslim'? Social-psychological mechanisms explaining anti-Islamic prejudice amongst young people in the U.K. In Helbling, M. (Ed.), Islamophobia in Western Europe and North America (pp. 179-89). London: Routledge.

Cohen, S. (2001). States of Denial: Knowing about Atrocities and Suffering. London: Polity Press.

Ernst-Vintila, A., Delouvée, S. \& Roland-Lévy, C. (2011). Under threat: Lay thinking about terrorism and the three-dimensional model of personal involvement - a social psychological analysis. Journal of Risk Research, 14(3), 297-324. 
Jaspal, R. (in press). Anti-Semitism and anti-Zionism in Iran: the role of identity processes. Israel Affairs.

Jaspal, R. (2011). The construction and management of national and ethnic identities among British South Asians: an identity process theory approach. Ph.D. dissertation, Royal Holloway, University of London, UK.

Jaspal, R. \& Cinnirella, M. (2010). Media representations of British Muslims and hybridised threats to identity. Contemporary Islam: Dynamics of Muslim Life, 4(3), 289-310.

Jaspal, R. \& Nerlich, B. (in press). When climate science became climate politics: British media representations of climate change in 1988. Public Understanding of Science.

Jaspal, R. \& Yampolsky, M. (2011). Social representations of the Holocaust and Jewish Israeli identity construction: insights from identity process theory. Social Identities, 17(2), 201-224.

Jiheli, G. (2009). Antisemitism among young Muslims in London. Paper presented at the International Study Group Education and Research on Antisemitism Colloquium 1: Aspects of Antisemitism in the UK, 5 December 2009. http://www.iibsa.org/cms/fileadmin/downloads/london_symposia/Gunther_Jikeli.pdf

Kelman, H. C. (1976). Violence without restraint: Reflections on the dehumanization of victims and victimizers. In G. M. Kren \& L. H. Rappoport (Eds.), Varieties of Psychohistory (pp. 282-314). New York: Springer

Klein, A. (2009). Characterizing "the Enemy”: Zionism and Islamism in the Iranian and Israeli Press . Communication, Culture \& Critique, 2, 387-406.

Kressel, N.J. (2007). Mass hatred in the Muslim and Arab world: the neglected problem of anti-Semitism. International Journal of Applied Psychoanalytic Studies, 4(3), 197-215.

Küntzel, M. (2010). Iranian anti-Semitism: stepchild of German National Socialism. Israel Journal of Foreign Affairs, 4(1) 43-51.

Lewis, B. (2003). The Crisis of Islam. New York: Modern Library.

Litvak, M. (2006). The Islamic Republic of Iran and the Holocaust: Anti-Semitism and AntiZionism. Journal of Israeli History, 25(1), 267-84

Mahdi, A.A. (2003). Iranian women: Between Islamicization and globalization. In A. Mohammadi's (Ed.), Iran Encountering Globalization: Problems and Prospects. London: Routledge.

Moscovici, S. (1988). Notes towards a description of social representations. European Journal of Social Psychology, 18, 211-250. 
Moscovici, S. \& Hewstone, M. (1983). Social representations and social explanations: from the 'naive' to the 'amateur' scientist. In M. Hewstone (Ed.), Attribution Theory: Social and Functional Extensions (pp. 99-125). Oxford: Blackwell.

Palmer-Harik, J. (2004). Hezbollah: The Changing Face of Terrorism. London, I.B. Tauris \& Co Ltd

Philo, G., \& Berry, M. (2004). Bad News From Israel. London: Pluto Press

Rouquette, M.-L. (1994). Sur la connaissance des masses. Grenoble: Presses Universitaires de Grenoble.

Semati, M. (2008). Media, Culture and Society in Iran: Living with Globalization and the Islamic State. London: Routledge.

Shahvar, S. (2009). The Islamic Regime in Iran and Its Attitude towards the Jews: The Religious and Political Dimensions. Immigrants \& Minorities, 27(1), 82-117.

Sweetser, K.D. \& Brown, C.W. (2010). An exploration of Iranian communication to multiple target audiences. Public Relations Review, 36, 238-248.

Tajfel, H. (1981). Human Groups and Social Categories: Studies in Social Psychology. New York: Cambridge University Press.

Takeyh, R. (2010). The Iran-Iraq War: A Reassessment. The Middle East Journal, 64(3), 365-383.

Van Dijk, T.A (1993). Principles of critical discourse analysis. Discourse \& Society, 4(2), 1993, 249-283.

Webman, E. (2010). The challenge of assessing Arab/Islamic antisemitism. Middle Eastern Studies, 46(5), 677-97.

\footnotetext{
${ }^{1}$ Tehran Times website, http://tehrantimes.com/nnnnnnnnnabout-ttnnnnnnnnn

${ }^{2}$ UK complicity in Iran terrors exposed, Press TV, 20 September 2011

${ }^{3}$ Israel navy siege: Gaza-bound French aid ship, Tehran Times, 19 July 2011

${ }^{4}$ Unholy peace and Israel's passivity, Press TV, 18 September 2011

${ }^{5}$ Iran calls for massive turn out on International Qods Day, Tehran Times, 24 August 2011

${ }^{6}$ Unholy peace and Israel's passivity, Press TV, 18 September 2011

${ }^{7}$ Demos are a sign of the decline of Israel's regional influence, Tehran Times, 8 August 2011

8 Demos are a sign of the decline of Israel's regional influence, Tehran Times, 8 August 2011

${ }^{9}$ Recognition of Palestinian state not the final step: Ahmadinejad, Tehran Times, 26 August 2011

${ }^{10}$ Assassination of Iranian academic is a U.S.-Israeli plot: officials, Tehran Times, 24 July 2011

${ }^{11}$ Ali-Mohammadi assassin will stand trial today: Tehran prosecutor, Tehran Times, 22 August 2011

12 Iran denounces Israeli air strikes on Palestinians, Tehran Times, 20 August 2011

${ }^{13}$ Palestinians pay tribute to 1976 martyr, Press TV, 11 October 2011

${ }^{14}$ Turks: Israeli footballers unwelcome, Press TV, 16 September 2011

${ }^{15}$ Norway mass killer, Tehran Times, 25 July 2011

${ }^{16}$ Israelis burn mosque, Qur'ans, Press TV, 3 October 2011

${ }^{17}$ Israel razes mosque in West Bank, Press TV, 11 October 2011

18 'Zionism with not stop with Syria unrest', Press TV, 7 October 2011

19 'US deeply dependent on Zionist lobby', Press TV, 3 October 2011
} 
${ }^{20}$ Second Islamic Awakening on horizon, Press TV, 17 September 2011

${ }^{21}$ Anti-Zionist multimedia CD released in Tehran, Tehran Times, 24 August 2011

${ }^{22}$ Iran calls for massive turnout on International Qods Day, Tehran Times, 24 August 2011

${ }^{23}$ Iran calls on Arab cineastes to produce films promoting Islamic unity, Tehran Times, 07 August 2011 